Arq. Bras. Med. Vet. Zootec., v.68, n.3, p.805-813, 2016

\title{
Validation of an HPLC-UV method for the identification and quantification of bioactive amines in chicken meat
}

\author{
[Validação de metodologia por HPLC/UV para identificação e quantificação de aminas \\ bioativas em carne de frango de corte] \\ D.C.S. Assis ${ }^{1}$, L.D.M. Menezes ${ }^{2}$, A.L. Lima ${ }^{1}$, R.W.T. Klein ${ }^{2}$, L.G.D. Heneine ${ }^{3}$, L.J.C. Lara ${ }^{1}$, \\ L.V. Teixeira ${ }^{1}$, C.B.D. Ornellas ${ }^{1}$, S.V. Cançado ${ }^{1}$, T.C. Figueiredo ${ }^{1 *}$ \\ ${ }^{1}$ Escola de Veterinária - Universidade Federal de Minas Gerais - EV-UFMG - Belo Horizonte, MG \\ ${ }^{2}$ Instituto Mineiro de Agropecuária - IMA - Belo Horizonte, MG \\ ${ }^{3}$ Fundação Ezequiel Dias - FUNED - Belo Horizonte, MG
}

\begin{abstract}
A high-performance liquid chromatography with ultraviolet detection (HPLC-UV) method was validated for the study of bioactive amines in chicken meat. A gradient elution system with an ultraviolet detector was used after extraction with trichloroacetic acid and pre-column derivatization with dansyl chloride. Putrescine, cadaverine, histamine, tyramine, spermidine, and spermine standards were used for the evaluation of the following performance parameters: selectivity, linearity, precision, recovery, limits of detection, limits of quantification and ruggedness. The results indicated excellent selectivity, separation of all amines, a coefficient of determination greater than 0.99 and recovery from 92.25 to $102.25 \%$ at the concentration of $47.2 \mathrm{mg} \cdot \mathrm{kg}^{-1}$, with a limit of detection at $0.3 \mathrm{mg} \cdot \mathrm{kg}^{-1}$ and a limit of quantification at $0.9 \mathrm{mg} \cdot \mathrm{kg}^{-1}$ for all amines, with the exception of histamine, which exhibited the limit of quantification, of $1 \mathrm{mg} \cdot \mathrm{kg}^{-1}$. In conclusion, the performance parameters demonstrated adequacy of the method for the detection and quantification of bioactive amines in chicken meat.
\end{abstract}

Keywords: validation, chicken meat, bioactive amines, HPLC-UV

\section{RESUMO}

Um método de cromatografia líquida de alta eficiência (CLAE) para pesquisa de aminas bioativas em carne de frango foi validado. Foi utilizado um sistema de gradiente de eluição com detector ultravioleta, após extração com ácido tricloroacético e derivação pré-coluna com cloreto de dansila. Os padrões de putrescina, cadaverina, histamina, tiramina, espermidina e espermina foram utilizados para avaliação dos seguintes parâmetros de desempenho: seletividade, linearidade, precisão, recuperação, limites de detecção, limites de quantificação e robustez. Os resultados mostraram excelente seletividade e separação de todas as aminas, coeficiente de determinação superior a 0,99, recuperação entre 92,25 e $105,25 \%$ na concentração $47,2 \mathrm{mg} \cdot \mathrm{kg}^{-1}$, limites de deteç̧ão de $0,3 \mathrm{mg} \cdot \mathrm{kg}^{-1}$ e limite de quantificação de $0,9 \mathrm{mg} . \mathrm{kg}^{-1}$ para todas as aminas, com exceção da histamina, que apresentou o limite de quantificação mais alto, de $1 \mathrm{mg} . \mathrm{kg}^{-1}$. Foi concluído que os parâmetros de desempenho demonstraram adequação do método para detecção e quantificação de aminas bioativas em carne de frango.

Palavras-chaves: validação, carne de frango, aminas bioativas, HPLC-UV

\section{INTRODUCTION}

Chicken meat has high nutritional value and is rich in proteins, vitamins and minerals. However, this product is highly perishable and is

Recebido em 11 de agosto de 2015

Aceito em 5 de janeiro de 2016

*Autor para correspondência (corresponding author)

E-mail: tadeu@vet.ufmg.br susceptible to many alterations that may produce unwanted substances. Biogenic amines are organic bases of low molecular weight that can be formed during the storage or processing of food products through the decarboxylation of amino acids by microbial enzymes (Brink et al., 1990). 
The consumption of food with high amine content can be harmful to health, potentially leading to histamine poisoning, migraine, or hypertensive crisis (Palencia et al., 2011). Approximately $30 \%$ of individuals with classical migraine may have a crisis when they consume tyramine-rich food (Glória and Vieira, 2007). At high concentrations, putrescine and cadaverine may lead to hypotension, bradycardia, exaggerated muscle contraction of the jaw, limb paralysis, and potentiation of the toxicity of other amines (Veciana-Nogués et al., 1997). Hence, the study of biogenic amines is important not only due to their toxicity but also because they can be used as food quality indicators. In this sense, the development of methodologies able to detect toxic compounds has been increasingly pursued to ensure that food products are not associated with any type of risk for the consumer.

The validation of analytical methods is required when the method to be employed is not yet recognized or approved by regulatory agencies and should always be performed when an existing method is modified to meet specific requirements, to ensure that its performance characteristics fulfill the requirements for the intended analytical operations (EURACHEM, 1998). The validation process allows demonstrating that a test method has the necessary characteristics to guarantee results with the required quality, therefore ensuring the reliability of the results under the conditions in which the method is employed (Lanças, 2004; Ribani et al., 2007).

High-performance liquid chromatography (HPLC) methods have been used by many authors for the analysis of bioactive amines in chicken meat (Baston et al., 2010; Buňkova et al., 2010). However, the used methodologies in the above mentioned articles were not validated. The lack of validated methods for the analysis of these compounds in chicken meat can generate unreliable results, which are not officially recognized by international authorities and the scientific community (Baston et al., 2008). There is an HPLC-UV validated method for the analysis of bioactive amines in chicken meat (Lázaro et al., 2013). Nevertheless, there are several differences in the described methodology, especially in the extraction procedures and derivatization process.
Thus, the purpose of this study was to validate a quantitative HPLC method with ultraviolet detection (HPLC-UV) for the study of bioactive amines in chicken breast meat.

\section{MATERIAL AND METHODS}

Samples of chicken (Gallus gallus domesticus) breast meat were directly collected from meat packing industries and transported to the laboratory in isothermal boxes with ice.

For amine extraction, the samples were ground, and a $5 \mathrm{~g}$ aliquot was directly weighted in $50 \mathrm{~mL}$ polypropylene centrifuge tubes before the addition of $7 \mathrm{~mL}$ of $50 \mathrm{~g} . \mathrm{L}^{-1}$ trichloroacetic acid (TCA 50g. $\mathrm{L}^{-1}$ ). The tubes were agitated for $10 \mathrm{~min}$ in a mechanical shaker at 200RPM (Tecnal, São Paulo, Brazil) and centrifuged at $5,232 \times \mathrm{g}$ at $4^{\circ} \mathrm{C}$ for $25 \mathrm{~min}$ in a refrigerated centrifuge (Cientec, São Paulo, Brazil). After the first centrifugation step, the supernatant was filtered through a Whatman no. 1 filter paper. This procedure was repeated two more times with the addition of $7 \mathrm{~mL}$ and $6 \mathrm{~mL}$ of TCA $50 \mathrm{~g} . \mathrm{L}^{-1}$, for a total of $20 \mathrm{~mL}$ of acid added in three successive extraction steps $(7 \mathrm{~mL}, 7 \mathrm{~mL}$, and $6 \mathrm{~mL})$. The resulting extracts were stored in $0.5 \mathrm{~mL}$ microtubes and frozen at $-20^{\circ} \mathrm{C}$ for later application of the derivatization process and chromatographic analysis.

For the derivatization process, $200 \mu \mathrm{L}$ of the extract was transferred to propylene centrifuge tubes, and $400 \mu \mathrm{L}$ of saturated sodium bicarbonate solution and $800 \mu \mathrm{L}$ of dansyl chloride solution were added. Next, the tubes were vortexed for approximately 30 seconds and kept in the dark in a hot water bath at $60^{\circ} \mathrm{C}$ for five minutes. After this step, $200 \mu \mathrm{L}$ of L-Proline solution were added, and the tubes were vortexed again for 30 seconds and stored in the dark, at room temperature, for $30 \mathrm{~min}$. Then, $1,000 \mu \mathrm{L}$ of toluene was added to the solution, which was vortexed for one minute for posterior centrifugation at $4,350 \mathrm{xg}$ for $10 \mathrm{~min}$ at $4^{\circ} \mathrm{C}$, for phase separation. The organic phase (supernatant) was recovered with an automatic pipette to a $5 \mathrm{~mL}$ test tube and taken to the sample concentrator for evaporation by the addition of nitrogen flow for $10 \mathrm{~min}$ at $60^{\circ} \mathrm{C}$. 
The resulting extract was dissolved in $600 \mu \mathrm{L}$ of acetonitrile and filtered using a filtration unit in polytetrafluoroethylene (PTFE) membrane, 0.45 $\mu \mathrm{m}$ pore size, and diameter from 13 to $15 \mathrm{~mm}$ (Millipore Corp, Milford, MA, USA). The filtrate was reserved for injection.

The amine standards (spermine tetrahydrochloride, spermidine trihydrochloride, putrescine dihydrochloride, cadaverine dihydrochloride, histamine dihydrochloride, and tyramine chloride) were purchased from Sigma Chemical Co. (St. Louis, MO).

Trichloroacetic acid (TCA) from Sigma-Aldrich (St Louis, MO, USA), and toluene, acetonitrile, and sodium bicarbonate from Merck (Darmstadt, Germany) were used. All of the reagents and chemicals used were of analytical purity (a.p.) grade, except for the solvents used in HPLC, which were of HPLC grade.

Stock solutions of each amine were prepared at a concentration of $1 \mathrm{mg} \cdot \mathrm{mL}^{-1}$ by dilution of the standards in $0.1 \mathrm{~N}$ hydrochloric acid $(\mathrm{HCl})$ and kept at $4 \pm 1^{\circ} \mathrm{C}$. After this procedure, $1 \mathrm{~mL}$ of each stock solution was transferred to a volumetric flask, resulting in a standard solution with a final concentration of $0.1666 \mu \mathrm{g} \cdot \mathrm{mL}^{-1}$ of each amine.

The derivatization solution was prepared by adding $750 \mathrm{mg}$ of dansyl chloride (SigmaAldrich ${ }^{\circledR}$, St. Louis, MO, USA) into $100 \mathrm{~mL}$ of acetone (LiChrosolv $\AA$, Merck, Darmstadt, Germany). The solution was kept at $-20^{\circ} \mathrm{C}$, while the L-proline solution (Merck, Darmstadt, Germany), which was prepared at the concentration of $100 \mathrm{mg} \cdot \mathrm{mL}^{-1}$ of ultrapure water (Milli-Q Plus System), was kept under refrigeration.

The chromatographic system consisted of a ÄKTAmicro ${ }^{\mathrm{TM}}$ (GE HealthCare, Buckinghamshire, England), equipped with two pumps (model P-900), a manual injector (model INV-907) with a $100 \mu \mathrm{L}$ loop, UV visible detector (UV-900), and the Unicorn 5.11 software (GE HealthCare, Buckinghamshire, England) for data processing. The chromatograms were processed in the $254 \mathrm{~nm}$ wavelength.

For the separation of amines, a Kromasil $\mathrm{C}_{18}$ chromatographic column $(5-\mu \mathrm{m}$ particle size,
100 Angstrom, $25 \mathrm{~cm} \times 4.6 \mathrm{~mm}$ ) (AkzoNobel, Amsterdam, The Netherlands) was used. The column temperature was $20^{\circ} \mathrm{C}$. The mobile phases water (A) and acetonitrile (B) were used and the elution program consisted of a gradient system with a $1.0 \mathrm{~mL} / \mathrm{min}$ flow-rate. The gradient applied was as follows: $60 \%$ to $75 \%(\mathrm{v} / \mathrm{v}) \mathrm{B}$ in $\mathrm{A}$ within $6.23 \mathrm{~min}$; maintained at $75 \%(\mathrm{v} / \mathrm{v}) \mathrm{B}$ in A for $2.38 \mathrm{~min}$; from $75 \%$ to $95 \%(\mathrm{v} / \mathrm{v}) \mathrm{B}$ in $\mathrm{A}$ within $6.27 \mathrm{~min}$; maintained at $95 \%(\mathrm{v} / \mathrm{v}) \mathrm{B}$ in A for $7.32 \mathrm{~min}$. The total run time was $31.66 \mathrm{~min}$. An injection of $100 \%(\mathrm{v} / \mathrm{v})$ A for $8.3 \mathrm{~min}$ was used between each sample to flush the HPLC system.

To validate the method for identifying bioactive amines in chicken breast meat, the following performance parameters were evaluated: selectivity, linearity, precision, accuracy, limit of detection (LoD), limit of quantification (LoQ), and ruggedness (Thompson et al., 2002).

Selectivity was evaluated by comparing the retention times of the amine standards added to the solvent (water) and in the presence of the matrix (chicken breast).

To evaluate linearity, the chicken breast matrix was fortified with the standard solution of the six amines at concentrations of $0.9,2.9,9.2,29.5$, and $94.4 \mathrm{mg} . \mathrm{kg}^{-1}$, using seven replicates. After analysis, a plot of peak area versus concentration was created, and the equations of the curves and the coefficients of determination $\left(\mathrm{R}^{2}\right)$ and correlation (r) were defined by linear regression (INMETRO, 2010).

The precision of the analyses was evaluated by determining the relative standard deviation (RSD) under repeatability conditions, using the results obtained by successive analysis of the same sample in short time intervals, and performed under the same conditions (same equipment and analyst). The chicken breast samples were supplemented by the standard solution at three concentration levels - low (2.9mg. $\left.\mathrm{kg}^{-1}\right)$, medium (47.2mg. $\left.\mathrm{kg}^{-1}\right)$, and high (94.4mg. $\left.\mathrm{kg}^{-1}\right)$, considering the method's linear interval, with three replicates each (ICH, 2005).

Accuracy was evaluated using recovery tests. Analyses of the method's linear interval at low (2.9mg. $\left.\mathrm{kg}^{-1}\right)$, medium (47.2mg. $\left.\mathrm{kg}^{-1}\right)$, and high (94.4mg. $\left.\mathrm{kg}^{-1}\right)$ concentrations were performed in 
triplicate. The recovery obtained at each concentration was calculated using the equation $\mathrm{R}=\left[\left(\mathrm{C}_{1}-\mathrm{C}_{2}\right) / \mathrm{C}_{3}\right] \mathrm{x} 100$, which considers the analytic concentration in the fortified sample $\left(\mathrm{C}_{1}\right)$, the analytic concentration in the nonfortified sample $\left(\mathrm{C}_{2}\right)$, and the analytic concentration added to the fortified sample $\left(\mathrm{C}_{3}\right)$ (EC, 2002; Codex Alimentarius, 2009).

The LoD and LoQ were calculated from equations that consider the parameters of the analytical curve, $\mathrm{LoD}=[(3 \mathrm{x} \sigma) / \mathrm{S}]$ and $\mathrm{LoQ}=[(10 \mathrm{x} \sigma) / \mathrm{S}]$, using the standard deviation of the response $(\sigma)$ and the slope of the analytical curve (S) (ICH, 2005).

The ruggedness of the method was evaluated by modifying two factors (analyst and day of analysis) during the analysis of the chicken breast meat samples (USP, 1995).

\section{RESULTS AND DISCUSSION}

The analytical method used to study bioactive amines in chicken breast meat exhibited good performance characteristics for all parameters evaluated, with excellent selectivity and separation of all amines, coefficient of determination $\left(\mathrm{R}^{2}\right)$ and correlation coefficient $(\mathrm{r})$ values greater than 0.99 , recovery coefficient from 92.25 to $105.25 \%$ (at the concentration of $\left.47.2 \mathrm{mg} \cdot \mathrm{kg}^{-1}\right)$, limits of detection equal to $0.3 \mathrm{mg} \cdot \mathrm{kg}^{-1}$ for all the amines, and limit of quantification from 0.9 to $1.0 \mathrm{mg} \cdot \mathrm{kg}^{-1}$ for the proposed method.

The analytical curves and coefficient of determination $\left(\mathrm{R}^{2}\right)$ from the analysis of amines added to chicken meat, obtained in the evaluation of linearity in the range of 0.9 to $94.4 \mathrm{mg} . \mathrm{kg}^{-1}$, are represented in Figure 1.

The values obtained show that the model is adequate because the coefficient of determination is greater than 0.99 , which is considered to be evidence of an excellent fit of the data to the regression line. According to the criteria of the European and Brazilian legislations, values higher than 0.99 are recommended for the linearity tests (EC, 2002; INMETRO, 2010). This parameter allows an estimation of the quality of the obtained curve because the closer to 1.0 its value is, the lower the dispersion of the set of experimental points and the lower the uncertainty of the estimated regression coefficients (Ribani et al., 2007).

The evaluation of selectivity (Figure 2) was performed by visual assessment of chromatogram (A), which shows the analysis of the standard solution of the six amines added to water at the concentration of $11.2 \mathrm{mg} \cdot \mathrm{kg}^{-1}$, as well as chromatogram (B), which represents the analysis of the chicken breast matrix with the addition of a standard solution of the six studied amines at the concentration of $94.4 \mathrm{mg} \cdot \mathrm{kg}^{-1}$.

The presence of a relevant peak (X) $(23.19 \pm 0.05$ min) that could not be identified was observed during the chromatographic run. This peak is most likely caused by the use of dansyl chloride as a derivatization agent. When evaluating different protocols for the determination of amines in fish, other authors also observed the emergence of an interfering peak and suggested that this phenomenon could be the result of reactions involving excess dansyl chloride (Malle et al., 1996). The use of different Lproline concentrations is an important procedure for the neutralization of excess dansyl chloride and to avoid the emergence of an interfering peak (Innocente et al., 2007). Hence, it is possible that the amount of L-proline added during the derivatization process was not sufficient to neutralize all of the dansyl chloride, thus allowing the emergence of this peak. Another relevant peak (Y) $(28.08 \pm 0.04 \mathrm{~min})$ was observed but could not be identified. However, the presence of such peaks did not interfere in the separation of amines because they do not elute at the same retention time as the peaks of interest.

The mean retention times of amines were $21.10 \pm 0.02 \mathrm{~min}$ for putrescine, $21.91 \pm 0.05 \mathrm{~min}$ for cadaverine, $22.40 \pm 0.04 \mathrm{~min}$ for histamine; $25.43 \pm 0.02 \mathrm{~min}$ for tyramine; $25.93 \pm 0.07 \mathrm{~min}$ for spermidine; and $28.99 \pm 0.01 \mathrm{~min}$ for spermine. The results showed that the detection occurred at the same retention time of the amines added to water when there was an addition of amines to the chicken breast matrix. Additionally, the peaks corresponding to the six amines could be differentiated from the other compounds present in the chicken breast matrix because no interfering peak eluted at the same retention times as the studied amines. Hence, the method could be considered to be selective. 


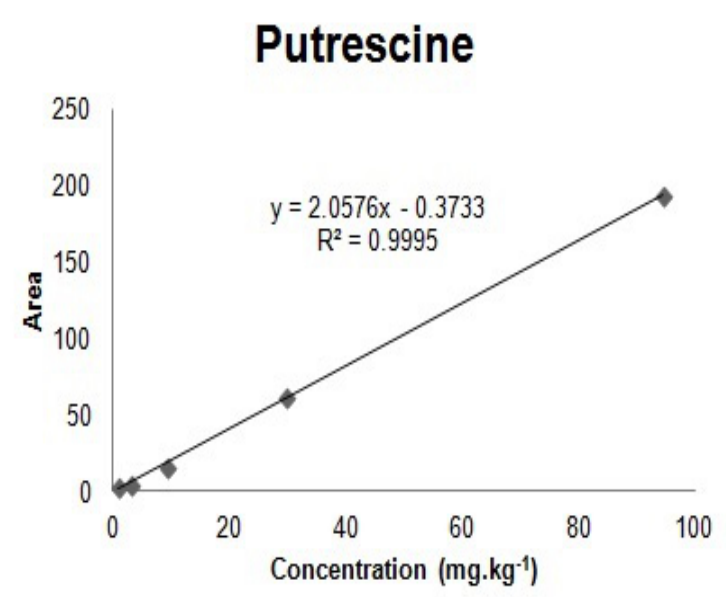

Histamine

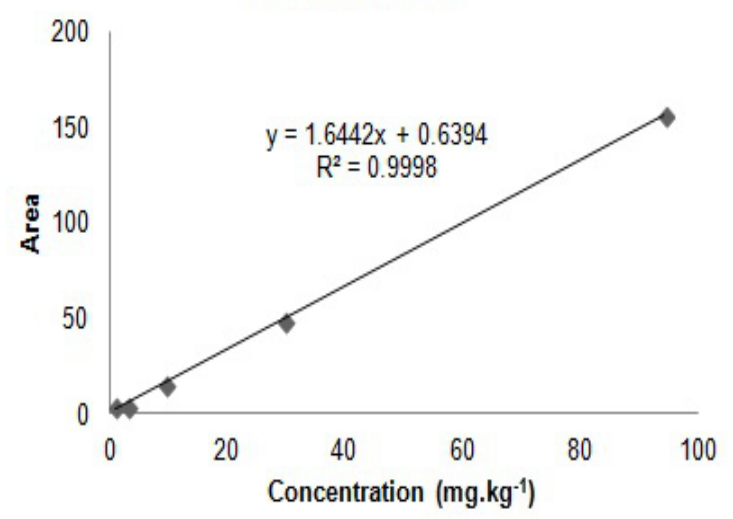

Spermidine

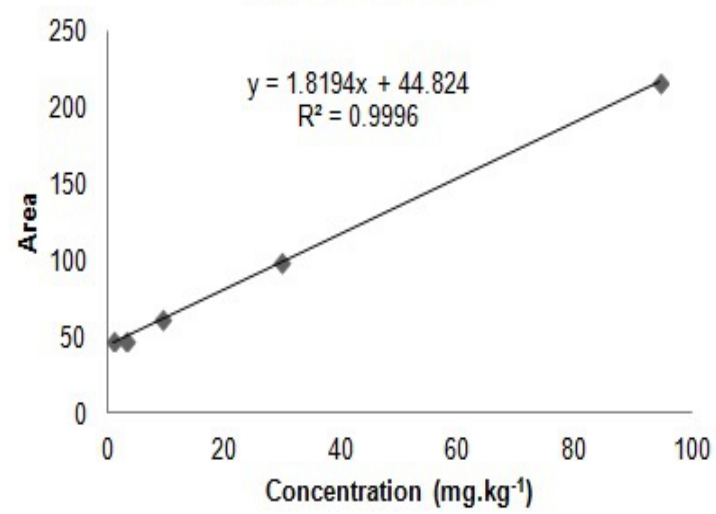

Cadaverine

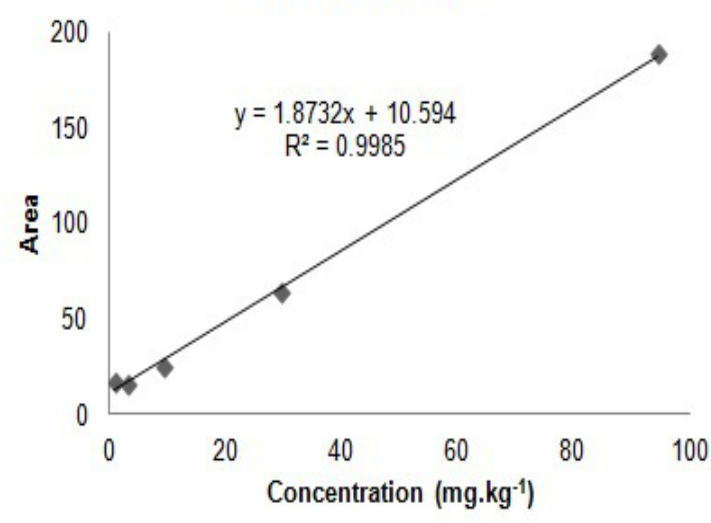

Tyramine

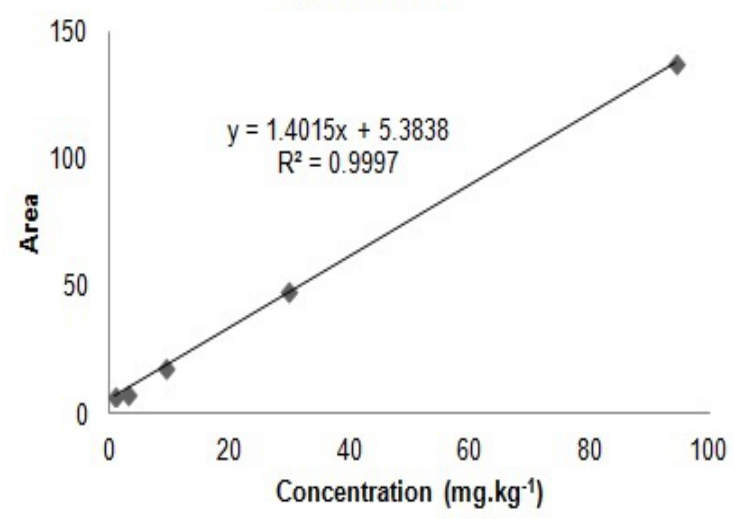

Spermine

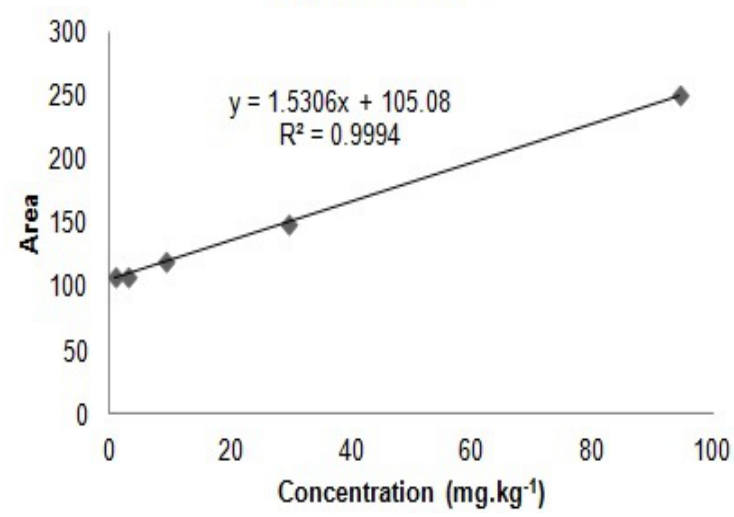

Figure 1. Linearity curves of the amines added to the chicken breast matrix in the range of 0.9 to 94.4mg. $\mathrm{kg}^{-1}$. 

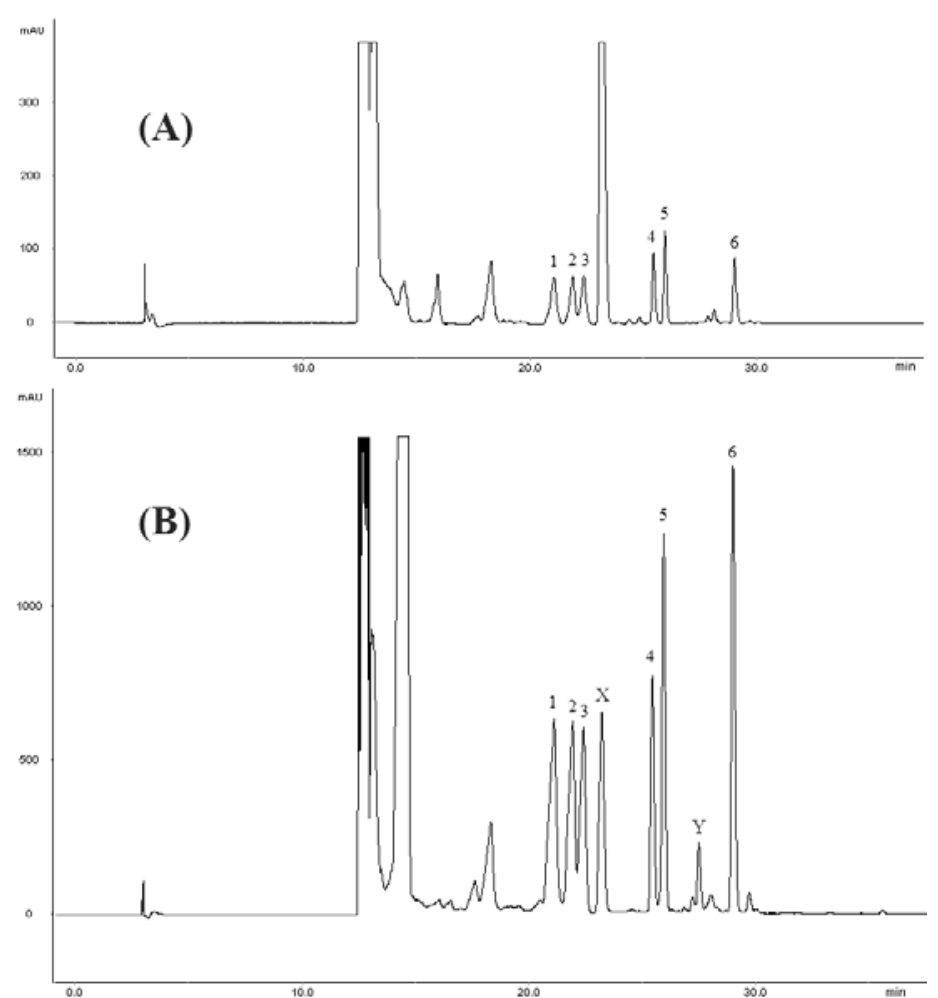

Figure 2. Chromatograms with the addition of a standard solution of the six amines $\left(11.2 \mathrm{mg}^{\mathrm{kg}} \mathrm{kg}^{-1}\right)$ to water (A) and addition of standard solution $\left(94.4 \mathrm{mg} \cdot \mathrm{kg}^{-1}\right)$ to chicken meat (B). 1 = putrescine, $2=$ cadaverine, 3 $=$ histamine, $4=$ tyramine, $5=$ spermidine and $6=$ spermine; $\mathrm{X}=$ interfering peak; $\mathrm{Y}=$ unidentified compound.

The LoD of the method was $0.3 \mathrm{mg} \cdot \mathrm{kg}^{-1}$ for all amines. The LoQ of the method was $0.9 \mathrm{mg} \cdot \mathrm{kg}^{-1}$ for all the amines, with the exception of histamine, with LoQ equal to $1 \mathrm{mg} \cdot \mathrm{kg}^{-1}$

Table 1 indicates the mean recovery percentages with new techniques used to evaluate the accuracy, while the RSD was still used for the evaluation of precision. The accuracy of the validated method was within the range recommended by the EC (2002) and the Codex Alimentarius (2009) which determine a recovery percentage from 70 to $110 \%$ and from 80 to $110 \%$, respectively, for analyte concentrations higher than 1mg.kg ${ }^{-1}$ (EC, 2002; Codex Alimentarius, 2009). However, the recovery of histamine at a concentration of $2.9 \mathrm{mg} \cdot \mathrm{kg}^{-1}$ was $120.9 \%$, which does not satisfy the specified values. Hence, the evaluated method exhibited satisfactory accuracy within the range of 2.9 to $94.4 \mathrm{mg} . \mathrm{kg}^{-1}$ for putrescine, cadaverine, tyramine, spermidine, and spermine.
The precision of the method exhibited satisfactory results for all six amines in the range of 2.9 to $94.4 \mathrm{mg} \cdot \mathrm{kg}^{-1}$. The RSD of the results obtained in the recovery tests ranged from 0.26 to $7.75 \%$. These values are within the range recommended by the EC (2002) and the Codex Alimentarius (2009) which predicts a maximum RSD of $10 \%$ for the concentration range evaluated in this study.

The results of the evaluation of the ruggedness of the method are described in Figure 3 and in Table 2. The changes in analysts and days of analysis did not compromise the determination of the levels of bioactive amines in the chicken breast meat. The standard deviations and the RSD values found for the samples evaluated on different days by the same analyst were low. Similarly, the variations between the two analysts were also small, indicating that the procedure is weakly influenced by these two factors. 
Validation of an HPLC-UV...

Table 1. Mean recovery percentages and relative standard deviation values of amines in the chicken breast matrix

\begin{tabular}{lccl}
\hline Amine & Concentration $\left(\mathrm{mg} \cdot \mathrm{kg}^{-1}\right)$ & Recovery $(\%)$ & RSD $(\%)$ \\
\hline \multirow{3}{*}{ PUT } & 2.9 & 70.024 & 7.75 \\
& 47.2 & 105.20 & 3.83 \\
CAD & 94.4 & 106.54 & 4.88 \\
& 2.9 & 70.761 & 3.23 \\
& 47.2 & 92.250 & 6.56 \\
HIS & 94.4 & 99.461 & 1.41 \\
& 2.9 & 120.902 & 6.17 \\
& 47.2 & 100.281 & 1.63 \\
TYR & 94.4 & 102.168 & 0.76 \\
& 2.9 & 104.597 & 3.39 \\
& 47.2 & 101.502 & 5.91 \\
SPD & 94.4 & 102.269 & 3.41 \\
& 2.9 & 99.747 & 2.47 \\
& 47.2 & 98.194 & 4.26 \\
SPM & 94.4 & 98.629 & 2.81 \\
& 2.9 & 100.391 & 0.26 \\
\hline
\end{tabular}

$\mathrm{RSD}=$ relative standard deviation; $\mathrm{PUT}=$ putrescine; $\mathrm{CAD}=$ cadaverine; $\mathrm{HIS}=$ histamine; $\mathrm{TYR}=$ tyramine; $\mathrm{SPD}=$ spermidine; $\mathrm{SPM}=$ spermine.
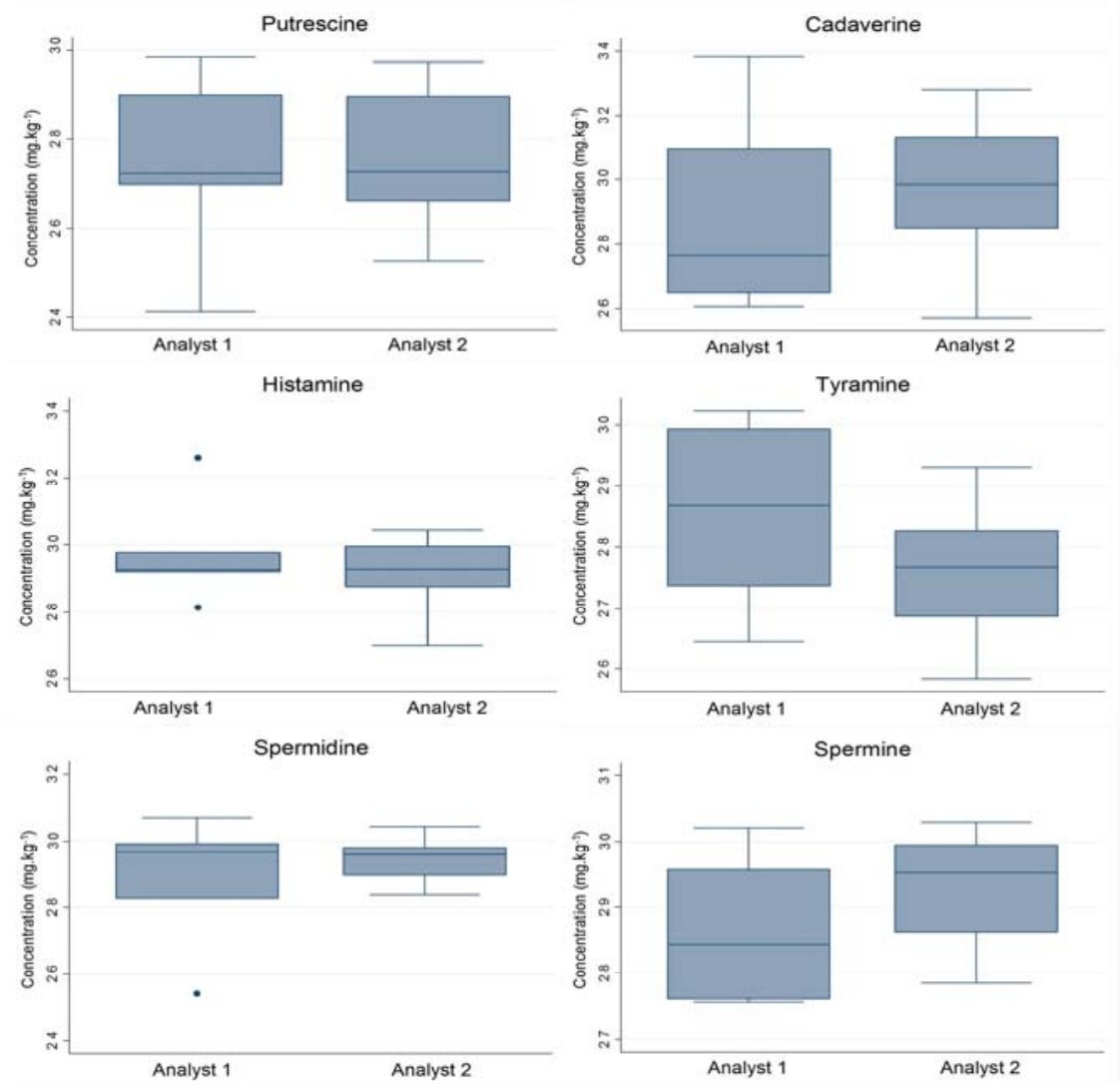

Figure 3. Boxplots of the analysis of biogenic amines in chicken breast meat performed by different analysts during the six-day period. 
Assis et al.

Table 2. Results of the analysis of biogenic amines in chicken breast meat performed by different analysts during the six-day period

\begin{tabular}{lllllllllll}
\hline Amine & Analyst & Day 1 & Day 2 & Day 3 & Day 4 & Day 5 & Day 6 & Mean & s & RSD (\%) \\
\hline \multirow{3}{*}{ PUT } & 1 & 2.745 & 2.985 & 2.701 & 2.700 & 2.901 & 2.413 & 2.741 & 0.198 & 7.22 \\
& 2 & 2.662 & 2.897 & 2.757 & 2.697 & 2.975 & 2.525 & 2.752 & 0.163 & 5.93 \\
& Mean & 2.704 & 2.941 & 2.729 & 2.699 & 2.938 & 2.469 & 2.747 & 0.181 & 6.58 \\
CAD & 1 & 2.735 & 3.382 & 2.646 & 3.095 & 2.792 & 2.607 & 2.876 & 0.302 & 10.49 \\
& 2 & 2.850 & 3.024 & 3.130 & 2.570 & 2.949 & 3.281 & 2.967 & 0.245 & 8.25 \\
& Mean & 2.792 & 3.203 & 2.888 & 2.833 & 2.871 & 2.944 & 2.922 & 0.273 & 9.38 \\
HIS & 1 & 2.930 & 3.262 & 2.921 & 2.924 & 2.814 & 2.979 & 2.971 & 0.152 & 5.12 \\
& 2 & 2.960 & 2.896 & 2.995 & 2.699 & 2.876 & 3.043 & 2.911 & 0.121 & 4.16 \\
& Mean & 2.960 & 3.079 & 2.958 & 2.812 & 2.845 & 3.011 & 2.941 & 0.136 & 4.64 \\
TYR & 1 & 2.737 & 2.986 & 2.748 & 3.023 & 2.994 & 2.644 & 2.856 & 0.164 & 5.74 \\
& 2 & 2.931 & 2.826 & 2.712 & 2.824 & 2.687 & 2.584 & 2.761 & 0.123 & 4.47 \\
& Mean & 2.834 & 2.906 & 2.730 & 2.923 & 2.841 & 2.614 & 2.808 & 0.144 & 5.10 \\
SPD & 1 & 2.541 & 2.825 & 2.962 & 2.972 & 3.071 & 2.992 & 2.894 & 0.190 & 6.57 \\
& 2 & 2.897 & 2.939 & 2.979 & 3.044 & 2.837 & 2.979 & 2.946 & 0.073 & 2.46 \\
& Mean & 2.719 & 2.882 & 2.971 & 3.008 & 2.954 & 2.986 & 2.920 & 0.131 & 4.52 \\
SPM & 1 & 2.757 & 2.766 & 2.922 & 2.761 & 3.208 & 2.957 & 2.895 & 0.177 & 6.11 \\
& 2 & 3.030 & 2.994 & 2.965 & 2.863 & 2.940 & 2.785 & 2.929 & 0.090 & 3.08 \\
& Mean & 2.893 & 2.880 & 2.943 & 2.812 & 3.074 & 2.871 & 2.912 & 0.134 & 4.60 \\
\hline
\end{tabular}

$\mathrm{RSD}=$ relative standard deviation; $\mathrm{s}=$ standard deviations $\mathrm{PUT}=$ putrescine; $\mathrm{CAD}=$ cadaverine; $\mathrm{HIS}=$ histamine; $\mathrm{TYR}=$ tyramine; $\mathrm{SPD}=$ spermidine; $\mathrm{SPM}=$ spermine .

\section{CONCLUSION}

The ion-pair reversed-phase high-performance liquid chromatography (HPLC) method with ultraviolet detection (UV) after pre-column derivatization with dansyl chloride was validated in this study, and its use is thus adequate for the determination of bioactive amines in chicken meat.

\section{ACKNOWLEDGMENTS}

The authors acknowledge the assistance of the College of Postgraduate Studies on Animal Science at the Escola de Veterinária at the Universidade Federal de Minas Gerais (UFMG) and Pró-Reitoria de Pesquisa at the UFMG for providing funds for publication, the Conselho Nacional de Desenvolvimento Científico e Tecnológico $(\mathrm{CNPq})$ for providing scholarship and funds for researching. The authors also thank the Instituto Mineiro de Agropecuária (IMA) and the Fundação Ezequiel Dias (FUNED) for assisting with the analyses.

\section{REFERENCES}

BASTON, O.; BARNA, O.; VASILE, A. Microbiota and biogenic amines variation of chiken meat; comparison between white and red meat. Ann. Food Sci. Tecnol., v.11, p.69-73, 2010.

BASTON，O.; STROIA，A.L.; MOISE，D.; BARNA, O. Validation study of a HPLC method able to measure biogenic amines in chicken meat. Food Technol., v.31, p.44-50, 2008.

BRINK, B.T.; DAMINK, C.; JOOSTEN, H.M.L.J.; VELD, J.H.J.H. Occurrence and formation of biologically active amines in foods. Int. J. Food Microbiol., v.11, p.73-84, 1990.

BUŇKOVA, L.; BUŇKA, F.; KLČOVSKA, P. et al. Formation of biogenic amines by Gramnegative bacteria isolated from poultry skin. Food Chem., v.121, p.203-206, 2010.

COMMISSION Decision 2002/657/EC implementing Council Directive 96/23/EC concerning the performance of analytical methods and the interpretation of results. Off. $J$. Eur. Communities, L221, p.8-36, 2002. 
FITNESS for purpose of analytical methods. A laboratory guide to method validation. Teddington: LGC, 1998, 62p.

GLÓRIA, M.B.A.; VIEIRA, S.M. Technological and toxicological significance of bioactive amines in grapes and wines. In: benkeblia, $\mathrm{N}$. (Ed.). Food. United Kingdon: Global Science Books. 2007. p.258-270.

GUIDELINES for the design and implementation of national regulatory food safety assurance programme associated with the use of veterinary drugs in food producing animals. Viena: Fao, 2009 CAC/GL 71-2009, p.38.

INNOCENTE, N.; BIASUTTI, M.; PADOVESE, M.; MORET, S. Determination of biogenic amines in cheese using HPLC technique and direct derivatization of acid extract. Food Chem., v.101, p.1285-1289, 2007.

LANÇAS, F.M. Validação de métodos cromatográficos de análise. São Carlos, SP: RiMa, 2004. 62p.

LÁZARO, C.A.; CONTE-JÚNIOR, C.A.; CUNHA, F.L. et al. Validation of an HPLC Methodology for the Identification and Quantification of Biogenic Amines in Chicken Meat. Food Anal. Meths., v.6, p.1024-1032, 2013.

MALLE, P.; VALLE, M.; BOUQUELET, S. Assay of biogenic amines involved in fish decomposition. J. AOAC Int., v.79, p.43-49, 1996.

ORIENTAÇÕES sobre validação de métodos analíticos/[Guidelines for the validation of analytical methods]. DOQ-CGCRE-008. INMETRO, 2010. Revisão: 03, fevereiro/2010, p. 20 .
PALENCIA, P.F.; FERNÁNDEZ, M.; MOHEDANO, M.L. et al. Role of tyramine synthesis by food-borne Enterococcus durans in adaptation to the gastrointestinal tract environment. Appl. Environ. Microbiol., v.77, p.699-702, 2011.

RIBANI, M.; COLLINS, C.H.; BOTTOLI, C.B.G. Validation of chromatographic methods: Evaluation of detection and quantification limits in the determination of impurities in omeprazole. J. Chromatogr. A, v.1156, p.201-205, 2007.

TEXT and methodology Q2 (R1). In: INTERNATIONAL CONFERENCE ON HARMONIZATION. VALIDATION OF ANALYTICAL PROCEDURES. ICH, 2005. Available in: <http://www.ich.org $>$. Accessed in: 05 dez. 2011.

THOMPSON, M.; ELLISON, S.L.; WOOD, R. Harmonized guidelines for single-laboratory validation of methods of analisys. J. Pure Appl. Chem., v.74, p.835- 855, 2002.

UNITED STATES PHARMACOPEIA CONVENTION, 23.ed. National Formulary 18. USA: United States Pharmacopeial Convention, Inc., 1995.

VECIANA-NOGUES, M.T.; MARINE-FONT, A.; VIDAL-CAROU, M.C. Biogenic amines as hygienic quality indicators of tuna. Relationships with microbial counts, ATP-related compounds, volatile amines, and organoleptic changes. J. Agric. Food Chem., v.45, p.2036-2041, 1997. 